\title{
Role of Pinching on Floral and Yield Parameters in African Marigold (Tagetes erecta L.) cv. Local Selection
}

\author{
Manoj Kundu, B.S. Beniwal, Suresh Kumar* and Rajesh Lathar \\ Department of Horticulture, CCS Haryana Agricultural University, \\ Hisar-125004 (Haryana), India \\ *Corresponding author
}

\begin{tabular}{|c|c|}
\hline & A B S T R A C T \\
\hline $\begin{array}{l}\text { Ke y w or d s } \\
\text { African marigold, } \\
\text { Pinching, Floral } \\
\text { characters, Yield } \\
\text { parameters }\end{array}$ & \multirow{3}{*}{$\begin{array}{l}\text { Field experiment was conducted during } 2004-05 \text { and } 2005-06 \text { at CCS Haryana } \\
\text { Agricultural University, Hisar to study the optimum time of pinching for better flower } \\
\text { production in African marigold cv. Local selection. There were six levels of pinchings i.e. } \\
\text { No pinching, } 7 \text { DAT (days after transplanting), 14 DAT, } 21 \text { DAT, } 28 \text { DAT and } 35 \text { DAT). } \\
\text { A uniform dose of nitrogen @ } 20 \mathrm{~g} / \mathrm{m}^{2} \text {, phosphorus @ } 10 \mathrm{~g} / \mathrm{m} 2 \text {, potassium @ } 10 \mathrm{~g} / \mathrm{m} 2 \text { and } \\
10 \mathrm{~kg} \text { FYM per plot }(1.2 \mathrm{~m} \times 1.2 \mathrm{~m} \text { ) was applied. For statistical analysis factorial } \\
\text { randomized block design was used with three replications. Pinching at } 28 \text { DAT } \\
\text { significantly improved the days to bud initiation, number of buds per plant, days to } \\
\text { flowering, duration of flowering, stalk length. The maximum flower weight, dry flower } \\
\text { weight, number of flowers per plant, flower yield per plant and flower yield per hectare } \\
\text { was obtained at } 28 \text { DAT. }\end{array}$} \\
\hline Article Info & \\
\hline $\begin{array}{l}\text { Accepted: } \\
\text { 10 April } 2019 \\
\text { Available Online: } \\
10 \text { May } 2019\end{array}$ & \\
\hline
\end{tabular}

\section{Introduction}

Among the many flowering plants in India, marigold is one of very important ones. Its cultivation has done very well on commercial scale in northern part of India. The loose flower marketing has been practiced for worship, garland making, general decoration. Due to more urbanization and increasing aesthetic value in modern society and civilization, the demand of the loose flowers is increasing tremendously. There is a tremendous scope of improvement in agrotechnology of flower crops. A wealth of data can be generated for better understanding and better quality of flowers. There are various factors which are responsible for higher production of marigold viz., variety, time of planting, fertilizer application, spacing, cultural practices like pinching, use of plant growth substances, irrigation etc. Therefore, the present investigation was planned and undertaken with the objective to standardize the time of pinching in African marigold.

\section{Materials and Methods}

The present investigation was carried out at the Department of Horticulture, CCS Haryana Agricultural University, Hisar, India for two years, during 2004 and 2005. 
Effect of pinching in growth, flowering and yield of African marigold cv. Local selection

\section{Treatments: Six}

$\mathrm{T}_{1} \quad$ : No pinching

$\mathrm{T}_{2} \quad$ : Pinching at 7 days after transplanting

$\mathrm{T}_{3} \quad$ : Pinching at 14 days after transplanting

$\mathrm{T}_{4} \quad$ : Pinching at 21 days after transplanting

$\mathrm{T}_{5} \quad$ : Pinching at 28 days after transplanting

$\mathrm{T}_{6} \quad$ : Pinching at 35 days after transplanting

\section{Replications: Three}

Design : Randomised Block Design (Factorial)

Plot size: $1.2 \mathrm{~m} \mathrm{x} 1.2 \mathrm{~m}$

Spacing: $40 \mathrm{~cm} \times 40 \mathrm{~cm}$

Cultivar: Local selection (MGH 160-8)

Fertilizer Dose: Uniform dose of FYM $(10 \mathrm{~kg} / \mathrm{plot})$, nitrogen $\left(20 \mathrm{~g} / \mathrm{m}^{2}\right)$, phosphorus $\left(10 \mathrm{~g} / \mathrm{m}^{2}\right)$ and potash $\left(10 \mathrm{~g} / \mathrm{m}^{2}\right)$ were applied as basal application

\section{Results and Discussion}

\section{Floral parameters}

Pinching of plants at different intervals proved effective in influencing the floral development in terms of days to bud initiation, number of buds, days to flowering, duration of flowering, size of flower and stalk length of flower (Table 1).

It is evident from the data that the days to bud initiation, days to flowering and duration of flowering delayed significantly with the pinching up to 28 DAT. The delay in these floral parameters due to late pinching might be attributed to the fact that during the process of pinching physiologically mature portion of the shoot was removed and the new shoots which developed on the pinched plants took more time for initiation of reproductive phase and become physiologically mature. Similar observations have already been made in marigold by Singh and Arora (1980); Arora and Khanna (1986) and Beniwal et al., (2003) in chrysanthemum. Flower diameter increased non-significantly up to 28 DAT. Stalk length increased significantly in all the pinching treatment up to 28 DAT in 2004 whereas the results were non-significant in 2005.

\section{Yield parameters}

Fresh and dry weight of flower, number of flowers, flower yield per plant and yield per hectare increased in all the pinching treatments up to 28 days after transplanting as compared to no pinching (Table 2). Pinching at 35 days after transplanting in the yield parameters a non-significant decreasing trend was observed. This significant increase up to 28 days may be due to the increased number of branches, these results are in close conformity with the findings of Singh and Arora (1980); Arora and Khanna (1986); Kumar et al., (2002) and Chauhan et al., (2005) in marigold. Sasi Kumar and Raghava (2002) in carnation.

Pinching is an important cultural operation in African marigold. It was observed that all the pinching treatments increased plant spread, number of branches per plant, fresh and dry weight of the plant, whereas plant height and internodal length were decreased. Most desirable growth parameters were obtained with pinching at 28 DAT.

Maximum numbers of buds per plant, duration of flowering, diameter of flower and stalk length were obtained at 28 DAT. 
Table.1 Effect of pinching on floral parameters in African marigold

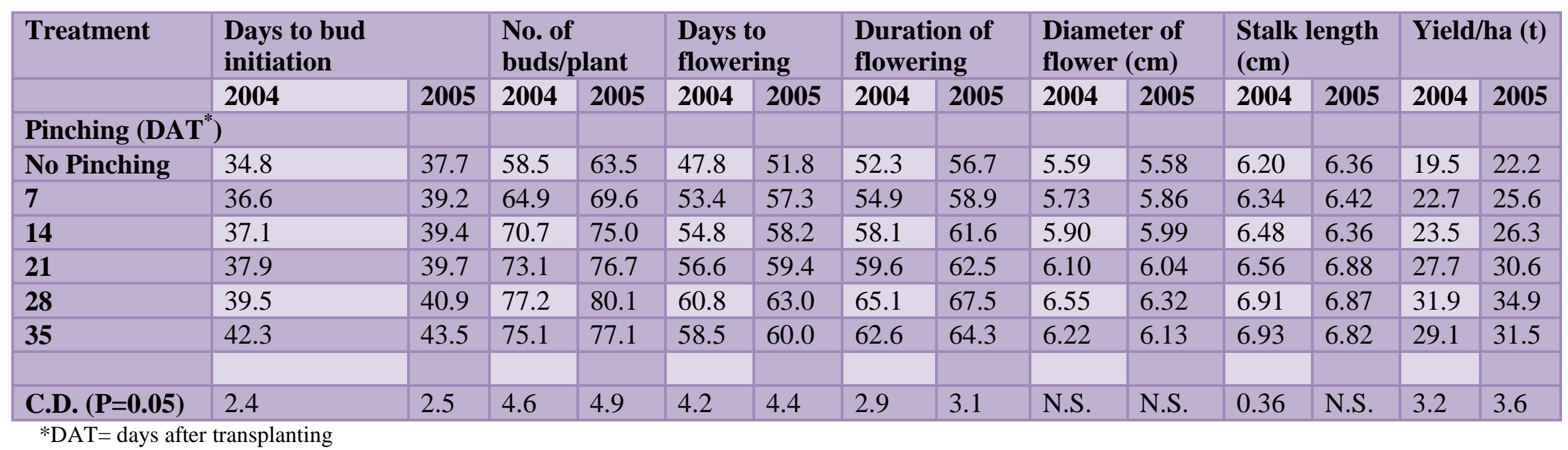

Table.2 Effect of pinching on yield parameters in African marigold

\begin{tabular}{|c|c|c|c|c|c|c|c|c|c|c|}
\hline \multirow[t]{2}{*}{ Treatment } & \multicolumn{2}{|c|}{$\begin{array}{l}\text { Flower weight } \\
\text { (g) }\end{array}$} & \multicolumn{2}{|c|}{$\begin{array}{l}\text { Dry flower weight } \\
\text { (g) }\end{array}$} & \multicolumn{2}{|c|}{$\begin{array}{l}\text { No. of flowers/ } \\
\text { plant }\end{array}$} & \multicolumn{2}{|c|}{$\begin{array}{l}\text { Flower yield/plant } \\
\text { (g) }\end{array}$} & \multicolumn{2}{|c|}{ Yield/ha (t) } \\
\hline & 2004 & 2005 & 2004 & 2005 & 2004 & 2005 & 2004 & 2005 & 2004 & 2005 \\
\hline \multicolumn{11}{|c|}{ Pinching (DAT $\left.{ }^{*}\right)$} \\
\hline No Pinching & 8.70 & 8.68 & 0.810 & 0.808 & 44.5 & 48.3 & 368.7 & 419.4 & 19.5 & 22.2 \\
\hline 7 & 9.00 & 8.89 & 0.849 & 0.838 & 49.6 & 53.2 & 420.7 & 473.1 & 22.7 & 25.6 \\
\hline 14 & 9.08 & 8.91 & 0.866 & 0.849 & 51.4 & 54.5 & 433.4 & 485.4 & 23.5 & 26.3 \\
\hline 35 & 9.60 & 9.21 & 0.944 & 0.905 & 60.0 & 61.6 & 524.0 & 567.2 & 29.1 & 31.5 \\
\hline C.D. $(P=0.05)$ & 0.73 & 0.71 & 0.070 & 0.068 & 1.7 & 1.8 & 43.7 & 48.4 & 3.2 & 3.6 \\
\hline
\end{tabular}

\footnotetext{
*DAT= days after transplanting
} 
The diameter of flower and stalk length were not affected significantly. Days to bud initiation were significantly delayed due to pinching at 28 DAT. All the pinching treatments resulted in significant improvement in yield parameters. However, pinching the plants at 28 DAT, maximum fresh and dry weight of plant, number of flowers, flower yield per plant and yield per hectare were obtained. Maximum number of seeds per capitulum, seed yield per plant, 1000 seed weight and seed vigour were observed when the plants were pinched at 28 DAT. Results were significant only with regard to number of seeds per capitulum and seed yield per plant.

\section{References}

Singh, J., and Arora, J.S., 1980. Effect of spacing and pinching on growth and flower production of marigold (Tagetes erecta L.) cv. African Giant Double Orange. Proc. National Seminar on production technology for commercial flower crops held at
T.N.A.U., Coimbatore. pp. 85-87.

Arora, J.S., and Khanna, K. 1986. Effect of nitrogen and pinching on growth and flower production of marigold (Tagetes erecta L.). Indian J. Hort. 43(3): 291-294.

Beniwal, B.S., Ahlawat, V.P. and Rakesh. 2003. Studies on the effect of spacing and pinching on growth and flower production of chrysanthemum cv. Flirt. Haryana J. Hort. Sci. 32(3\&4): 228-229.

Kumar, R., Singh, K. and Reddy, B.S. 2002. Effect of planting time, photoperiod. $\mathrm{GA}_{3}$ and pinching in carnation. $J$. Ornamental Hort. 5(2): 20-23.

Chauhan, S., Singh, C.N. and Singh, A.K. 2005. Effect of vermicompost and pinching on growth and flowering in marigold cv. Pusa Narangi Gainda. Prog. Hort. 37(2): 419-422.

Sasi Kumar, K., and Raghava, S.P.S. 2002. Effect of pinching in African marigold. Abst. National Symposium on Indian Floriculture in New Millennium. Pp. 35.

\section{How to cite this article:}

Manoj Kundu, B.S. Beniwal, Suresh Kumar and Rajesh Lathar. 2019. Role of Pinching on Floral and Yield Parameters in African Marigold (Tagetes erecta L.) cv. Local Selection. Int.J.Curr.Microbiol.App.Sci. 8(05): 812-815. doi: https://doi.org/10.20546/ijcmas.2019.805.096 